\begin{tabular}{lr} 
Hacettepe Üniversitesi iktisadi ve İdari Bilimler Fakültesi Dergisi \\
Hacettepe University Journal of Economics and Administrative Sciences \\
https://dergipark.org.tr/tr/pub/huniibf \\
ISSN:1301-8752 & E-ISSN:1309-6338 \\
\hline $\begin{array}{l}\text { Başvuru Tarihi / Submission Date: 31/01/2021 } \\
\text { Kabul Tarihi / Acceptance Date:02/11/2021 }\end{array}$ & DOI:10.17065/huniibf.871791 \\
\hline
\end{tabular}

Araştırma Makalesi / Research Article

\title{
Turkish Economy in the 2000s: Productivity Changes in the Manufacturing Industry
}

Gülşah Özşahin ${ }^{1}$, Zühal Özbay Daş²

\begin{abstract}
This study aims to discuss the manufacturing and service sectors' productivity performances of Turkey during the 2000s. In order to get some ideas how structural changes are directed during the 2000s in Turkish manufacturing, shift-share analysis is applied in this study. The results reflect that between 2003 and 2007, in all manufacturing categories, labor productivity has decreased while during the period between 2010 and 2015, labor productivity has increased in all manufacturing categories. Labor productivity further increased for all groups, but at a slower pace for medium-low-technology categories and stagnant for high-technology industries during the period between 2016 and 2018. Labor productivity in the service sector shows a somewhat different pattern than that seen in manufacturing in terms of periods. Particularly in high-tech service groups, the static shift toward relatively lower labor productivity sectors has been observed for almost all periods. In less-knowledge-intensive services, labor productivity decreased in the first period, but increased most notably during the 2010-2015 period. The results supposedly imply that there is some room for discussion of the role of industrial policies, particularly in the post-2010 period. Moreover, after 2016, the change in the political and economic environment offers some clues in understanding the productivity changes in the manufacturing sector.
\end{abstract}

Keywords: Structural change, productivity, shift-share analysis, Turkey.

\section{0'li Yıllarda Türkiye Ekonomisi: İmalat Sanayinde Verimlilik Değişimleri}

Öz

Bu çalışmanın amacı, 2000'li yıllarda Türkiye'nin imalat ve hizmet sektörlerinin verimlilik performanslarını tartışmaktır. 2000'li yıllarda Türkiye imalatının yapısal değişiminin yönü konusunda fikir edinmek için bir ayrıştırma analizi uygulanmıştır. Sonuçlar, 20032007 döneminde tüm imalat kategorilerinde, emek verimliliğinin düştüğünü, buna karşın 2010-2015 döneminde tüm imalat kategorilerinde emek verimliliğinin artıı̆ını göstermektedir. 2016-2018 döneminde tüm gruplarda emek verimliliği daha da artmıştır, ancak, orta-düşük-teknoloji kategorisinde artış hızı daha yavaş, yüksek-teknoloji endüstrileri durağan bir görünüm sergilemiştir. Hizmet sektöründe emek verimliliği, dönemler itibarıyla imalatta görülenden biraz farklı bir yapı sergilemektedir. Özellikle yüksek teknolojili hizmet grubunda neredeyse tüm dönemlerde nispeten düşük verimli sektörlere doğru bir statik kayma gözlenmiştir. Daha az bilgi yoğun hizmetlerde, emek verimliliği ilk dönemde azalmış, ancak 2010-2015 döneminde belirgin biçimde artmıştır. Sonuçlar, özellikle 2010 sonrası dönemde sanayi politikalarının rolünü tartışmanın anlamlı olduğunu göstermektedir. Bununla birlikte, 2016 sonrasında siyasi ve ekonomik ortamdaki değişiklikler imalat sektöründeki verimlilik değişimlerinin anlaşılmasında ipuçları vermektedir.

Anahtar Kelimeler: Yapısal dönüşüm, emek verimliliği, shift-share analizi, Türkiye.

\footnotetext{
1 Sorumlu Yazar (Corresponding Author), Assist. Prof., Kırklareli University, Department of Economics, gulsah.ozsahin@klu.edu.tr, https://orcid.org/0000-0001-9384-1375.

${ }^{2}$ Assist. Prof., Fenerbahçe University, Department of Economics, zuhal.ozbay@fbu.edu.tr, https://orcid.org/0000-0002-8135-047X .
} 


\section{INTRODUCTION}

The global economy has experienced dramatic changes since the late 1990s. Due to huge improvements in IT technologies and reduction in transportation costs, international trade has accelerated and the production facilities expanded to the different parts of the world. At the same time, the share of developing economies in total world income has increased and some of the economies like Vietnam have moved into one step higher income level during those years.

After 2000, the world economy has shown different patterns. As Boratav (2019) suggested, the period can be technically divided into two sections: Period between 2002 and 2007 and post-2007 period. Huge financial flows into the peripheral economies were one of the main characteristics of the 2002-2007 period (Boratav, 2019). Orhangazi (2019) emphasized this situation by showing that worldwide the daily volume of foreign exchange transactions reached 3.2 trillion dollars on average in 2007 from 820 billion dollars in 1998. This period ended in 2008 when the global economy was hit by the worldwide crisis. While some of the emerging economies like Mexico, Argentina and Turkey experienced sharped declines in GDP growth rates, other emerging economies like China, India and Nigeria sustained high growth rates even during the global crisis. The European area was severely hit by the crises and both the US and the EU executed expansionary monetary policies, particularly quantitative easing, to revive their economies. Yet, Orhangazi (2019) shows that global liquidity reached historic levels during these years, and consequently net capital outflows were not reported, even in 2009. On the other hand, after 2017, things started to change with the introduction of restrictions on trade and Brexit. GDP growth forecasts have been downgraded and world trade has decelerated. ${ }^{1}$ However, it is noteworthy to mention that developing economies outperformed developed economies in 2017 and 2018 in world trade.

Even though emerging economies have become significant players in the world trade and global value chains (Gereffi, 2015) and manufacturing activities have shifted from the developed economies to developing economies, the developing economies have lately started to experience a deindustrialization process (excluding Asia), before achieving sustainable industrialization (Rodrik, 2016). The deindustrialization process is simply defined as the widespread and systematic withdrawal or the reduction in capital investments causing a reduction in the productive capacity ${ }^{2}$ (Van Neuss, 2016). This might be a problem in the future for those countries in terms of the process of catch-up with developed economies.

In this context, this paper aims to analyze the shifts between lower and higher productivity sectors in Turkey after 2000 by using shift-share analysis method. We extend the time period of the existing literature and include 2016-2018 period separately. This period is, we think, somewhat differentiated from the previous periods, due to political and economic atmosphere of the country. Besides, we incorporate the service sector to the analysis to further discuss as to whether there has been a shift in the service sector after 2000 in Turkey.

The next section is devoted to the literature review. The third section reviews recent developments in Turkey from the deindustrialization perspectives based on some selected statistics and shift-share analysis. The final section concludes.

\section{LITERATURE REVIEW}

Structural change occurs with the reallocation of labor between low and high productivity sectors; therefore, it can be growth reducing or increasing. The reallocation of production from the manufacturing sector to the service sector in many industrialized countries (particularly the USA and the UK) since the 1970 s has led to a large amount of literature on deindustrialization and sustainability of productivity growth. Also, more recently it is seen that many developing countries (such as Latin America, India and sub-Saharan Africa) have started to experience a deindustrialization process (Dasgupta and Singh, 2006; Timmer et al., 2014; Rodrik, 2016). In these countries, the share of industry (in particular the share of manufacturing) in total value added (also total employment) has started to decrease at much lower 
income per capita levels, and at much lower rates compared to the developed ones (Rodrik, 2016). Therefore, this phenomenon in the developing countries is named as "early deindustrialization" and "premature deindustrialization" (Dasgupta and Singh, 2006; Rodrik, 2016). As these countries run out of industrialization opportunities sooner, in the future this deindustrialization may cause developing economies to diverge from, rather than converge with, the developed economies. (Rodrik, 2016)

Rodrik (2016: 3) explains that manufacturing activities have some properties as an important instrument for economic growth, and early deindustrialization may cause detrimental consequences in the growth path. First, "manufacturing tends to be technologically a dynamic sector" and "exhibits unconditional labor productivity convergence." Second, it "has traditionally absorbed significant quantities of unskilled labor" in contrast to "other high-productivity sectors such as mining or finance." Third, "manufacturing is a tradable sector," and it is not constrained with the domestic demand of the country. Therefore, it can grow and employ workers independently of domestic technological conditions (Rodrik, 2016: 3).

In that sense, there is also a debate about whether advanced services are substitutes and/or complements to the manufacturing sector as the engine of growth, that is, linkages between manufacturing and services. Value-chain of individual products can be defined as three stages: "prefabrication activities (such as design, finance, and organizational services), fabrication activities (things done in factories), and post-fabrication activities (such as marketing, post-sales services, and the like)". The distribution of value added in manufactured products can be defined as a convex "smile-curve". Value distribution indicated a relatively flatter curve in the 1970s and 1980s; however, in the post-1990 period, value added in the fabrication stage has fallen and value addeds in pre-fabrication and post-fabrication stages have increased and the smile curve "deepened" (Baldwin, 2016: 154-164).

Kucera and Jiang (2019) construct "Hirschman compliance indices" using the World Input-Output Database, and with decomposition, they try to find out balanced versus unbalanced growth in eight emerging economies: Brazil, China, India, Indonesia, South Korea, Mexico, Russia and Turkey between 1995 and 2009. They also analyze the complementarity between manufacturing and financial, communication and business services with respect to intermediate inputs, and find that it is weak in eight emerging economies compared to the G7 countries (Kucera and Jiang, 2019). They show that in China, India and South Korea there is "an all-around increase in productivity" and "33 WIOD sectors contributed positively to aggregate labour productivity growth," and therefore they "experienced balanced growth" (Kucera and Jiang, 2019: 197).

The third debate is about probable reasons behind deindustrialization. Doğruel and Doğruel (2017: 51-52) state that there are two main axes that can affect deindustrialization: "economic policies and internal structure," such as "trade policies (policies facilitating imports), investment policies and sectoral choices pushing industry into the background" and "external conjuncture" such as "developments in global trade and investments (deindustrialization caused by globalization)."

In addition, Kose et al. (2009: 50) stated that financial globalization makes it easier for countries to finance their investments through foreign financial resources, however, the effect of financial globalization for developing countries may have mixed effects because benefits of financial globalization depend on "supporting conditions" including "stable macroeconomic policies as well as sufficiently strong financial and other institutions, regulation and governance." Without these conditions, the country might become "more vulnerable to sudden stops of capital flows" (Kose et al., 2009: 50). In a broader view, Hausmann et al. (2008)'s "growth diagnostics" framework can be included in the debate. Hausmann et al. (2008: 325) develop a framework for "growth diagnostics" and put forward a decision tree in order to find out what keeps investments and therefore growth low. Growth can be low because of: "inadequate returns to investment, inadequate private appropriability of the returns, or inadequate access to finance" (Hausmann et al., 2008: 325). 
The literature on structural transformation analyzes relative importance of reallocation of labor from lower to higher productivity sectors and changes in productivity within sectors on aggregate labor productivity growth using growth accounting decomposition methods (Timmer et al., 2014; Kucera and Jiang, 2019). Most of these studies show that changes within sectors and "employment reallocation effects" are drivers of aggregate labor productivity growth in developing countries (Timmer et al., 2014: 15; Kucera and Jiang, 2019: 193). Timmer et al. (2014: 21) analyze structural change in Asia, Africa and Latin America between 1950 and 2010 and show that in Africa, Asia, and Latin America the most important sector (leading sector) was the services sector, especially, trade and distribution services after 1990. They also reflect that Africa and Latin America expanded their manufacturing activities and experienced a growth enhancing structural change during the 1960s and the early 1970s; however, structural change stopped in the mid-1970s and 1980s. Nevertheless, according to them, after 1990, market activities such as retail trade and distribution services increased. Furthermore, they observe that "although productivity levels in market services were above the average for the rest of the economy, productivity growth was not," therefore, "static reallocation gains but dynamic losses" were observed in the economy (Timmer et al., 2014: 21). In Asia, the interaction term (showing dynamic losses) is small, which may indicate a greater dynamism in manufacturing (Timmer et al., 2014: 16).

Literature about structural change in Turkey includes studies that make international comparisons as well as national studies. Kucera and Jiang (2019: 193) show that, although in Turkey labor productivity growth is high and employment growth is low, "employment reallocation effects are greater than withinsector effects" between 1995 and 2009. Doğruel and Doğruel (2018b) decompose productivity changes in the Turkish manufacturing sector between 2003 and 2015 by using a shift-share analysis, and according to the results-both in the manufacturing sector as a whole and in technology sub-groups-labor productivity decreased before the 2008 financial crisis and increased after the crisis. Meçik and Aytun (2018) examine "early" deindustrialization in Turkey according to regions (at the provincial level) between 2003 and 2013. They found that new industrial centers in the central regions of Turkey have played an important role both in terms of employment and output, and medium-technology industries have come to the fore in terms of employment. However, they show that, in the western regions, the low- and medium-technology industries' shares in output were notably increased, while an increase in employment occurred only in medium-educated employment and in the medium-technology industries. Similarly, although the share of product in the eastern regions has increased, no improvement in the share of the manufacturing industry in employment has been observed (Meçik and Aytun, 2018). Bakır et al. (2017) calculate the manufacturing sector value-added shares and per-capita real income levels at which deindustrialization began for various groupings of countries (developed, emerging market and developing economies) as well as for Turkey, and make comparisons between them. They state that Turkey deindustrialized later than Latin American countries, but earlier than East Asian countries. Subsequently, Turkey continued to deindustrialize, even during the 2002-2008 period of financial expansion. According to the regression analyses for 1960-2014 and 1970-2013, the inverted U-shaped relationship between manufacturing share in GDP and GDP per capita is valid for Turkey. According to the regression analysis for the period 1970-2013, the effect of trade openness on the manufacturing share in GDP is positive, while the effect of financial openness is negative (Bakır et al., 2017).

This study, in that sense, aims to discuss the recent developments in productivity performances of the Turkish manufacturing industry by extending the time period of the existing literature and including 2016 and 2018 years when it seems that the period itself is distinguished from previous periods because of the political and economic atmosphere of the country. Moreover, the service sector is also incorporated to the analysis to broaden the discussion as to whether there has been a shift in the service sector during the period in Turkey. 


\section{RECENT DEVELOPMENTS IN TURKEY}

Since the beginning of the 2000s, Turkey has experienced fundamental economic and political changes. Turkey experienced a deep economic crisis in 2001, and the accompanying political and social turmoil led to the rise of the Justice and Development Party (Adalet ve Kalkınma Partisi or AKP) as a ruling party and the end of the short-lived coalition governments of the 1990s.

After the 1980s, middle-high income countries such as Argentina, Brazil, Mexico, Israel and Turkey implemented stabilization policies under the supervision of the IMF and the World Bank to resolve their macroeconomic imbalances (Doğruel and Doğruel, 2018a). In the following years, particularly after 2000, a global monetary expansion made it easier for developing countries to find capital resources. However, in this process certain fragilities such as current account deficits particularly in Turkey, and external debt remained as problems for these countries (Doğruel and Doğruel, 2018a) (Figure A3).

Yeldan and Yıldırım (2015: 81) underlined two phenomena in characterizing the Turkish economy in the 2000s: (1) "collapse of saving rate" and (2) "decrease in the share of manufacturing in income" (Figure A4). Yeldan and Yıldırım (2015) claim that in the decade after 2003 "current account balance deficit can be associated with external fragility and financial instability, on the one hand, and relative production losses and ongoing high unemployment, on the other" (Yeldan and Yıldırım, 2015: 81). They state that the decreased cost of foreign capital and the exchange rate have led to the substitution of domestic production and employment with imported intermediate and investment goods and encourage low technology and capital-intensive industrial production (Yeldan and Yıldırım, 2015).

Even though in the period after the 2000s the Turkish economy has common characteristics stated above, to see the picture more in detail, the era of the AKP can be divided into four sub-periods: the "rise" of the AKP between 2002 and 2007, global recession and "fall" for 2008 and 2009, "stagnation" between 2010 and 2015 (Boratav, 2019: 255), and the changing political atmosphere after 2016, including the currency crisis of 2018. Figure A2 shows logarithmic per-capita GDP levels at constant prices. It shows the difference in the growth trends of the periods 2002-2007, 2010-2015 and 2016-2018.

\subsection{2-2007 Period}

In the 2000s, in the economic environment that had been stabilized at the global level by the programs implemented and by developments in the financial markets, the macroeconomic indicators of the developing countries began to improve (Doğruel and Doğruel, 2018a). Figure A1 shows net financial inflows (financial account balance) and GDP growth rates in Turkey following financial liberalization in 1989. As global liquidity has risen to huge levels since the beginning of the 2000s, in Turkey net foreign capital inflows have reached unprecedented levels. Indeed, after the crisis years between 1998-2002 with annual GDP growth of 0.6\%, growth reached 7.5\% between 2003 and 2007. Dincer and Tekin-Koru (2019) explain that "the AKP was successful in capitalizing in its first years" due to IMF economic reforms and "a series of economic, political and institutional reforms" related to the "goal of EU membership" (Dincer and Tekin-Koru, 2019: 1).

In terms of sectoral development, the construction sector is supposed to be the main driver of employment growth during this period. Employment has increased by 156\% from 2003 to 2007 . Services experienced the second highest employment growth by $51.6 \%$ and employment growth in manufacturing was $27.1 \%$. All sectors, construction, services and manufacturing, have experienced a decline in the labor productivity in this period, except mining and quarrying and some sub-sectors: tobacco, beverages and manufacture of wood (Table A5). One explanation would be the regulations to decrease informality as Dincer and Tekin-Koru (2019) suggested. These regulations were "tax pardons and social security incentives" that led to a "huge influx of employment both with the entrance of small informal firms and informal employees of medium to large firms to the system" (Dincer and Tekin-Koru, 2019: 24). Still, change in the regulations in the labor market to reduce the informality might not cover the whole story in terms of reduction in productivity. In that sense, the next section is devoted to understanding the productivity shifts in broad manufacturing and service industry categories. 


\subsection{Global Crisis}

The financial crisis that began in the US in 2008, was also transmitted to the developing countries. Macroeconomic imbalances re-emerged in some of these countries, in particular Turkey and Argentina (Doğruel and Doğruel, 2018a: XIII-XIV). The Turkish economy contracted by $4.8 \%$ during the global recession year 2009.

\subsection{0-2015 Period}

Turkey entered a lower growth trend after the crisis (Doğruel and Doğruel, 2017). The economy experienced a period of recovery but with continuing effects of the global crisis and increasing domestic concerns. Growth rate has decreased to 6.7\% between 2010 and 2015 (Figure A2). Global liquidity flow has continued, after 2009, at higher levels as a result of the "quantitative easing" policies of developed country banks (Figure A1).

In this period, construction still contributed to the highest employment growth in Turkey (69.5\%). Orhangazi (2019) stated that the government adopted a "construction focused growth model" during this period. Orhangazi (2019) claimed that there are three factors affecting the increase in construction activities in Turkey. One is the acceleration of migration into cities and the decrease in the employment share in agriculture. This triggers the demand for housing in the cities. The second one is financial developments that it makes easier to access long term loans for housing with lower interest rates. The final one is that the government itself induces construction activities through urban renovation programs or construction of roads, airport through Turkey's government-backed housing agency, TOKi (Orhangazi, 2019). Moreover, between 2011 and 2015, "due to an overvalued Turkish lira, and a low interest rate policy in this period with a manufacturing sector that became more import dependent by the day, relative prices deteriorated against manufacturing. This in turn has caused manufacturing to lose its appeal and increased the attractiveness of the services sectors such as construction." (Dincer and Tekin-Koru, 2019: 8-9). Therefore, the striking increase in the employment in the construction sector is not a surprising outcome for both periods. Employment in the manufacturing sector, on the other hand, accelerated reaching $36.4 \%$ in this period. Contrary to the previous period, an increase in productivity is observed in construction $(7.6 \%)$, service $(11 \%)$ and particularly the manufacturing sector ( $18 \%$ increase).

\subsection{6-2018 Period}

The 2016-2018 period is also analyzed because the failed coup attempt in 2016 and the constitutional referendum in 2017 which cleared the way for the presidential system in Turkey, to some extent, changed the political atmosphere of the country. Öniş (2019) stated that the presidential system in Turkey becomes a system where "checks and balance mechanisms are largely absent and where the decision-making process is excessively concentrated in the hands of the executive." Öniş (2019) also underlined the decreasing role of parliament and its role on budgetary process and pointed out that some government agencies are directly accountable to the President in this presidential system. Therefore, the process itself is highly likely to change in the decision-making process on the economic issues in Turkey. Not surprisingly, "many other economic institutions, too, have encountered with redefining of their roles and powers through overnight decisions" (Öniş, 2019: 210).

Indeed, in $2019,20.8 \%$ of the firms view political instability as their biggest obstacle among other elements of business environment (ratio was $10.7 \%$ in 2013) after access to finance $(28.9 \%$ ) and tax rates (24.1\%) (World Bank Enterprise Survey, 2019). The growth rate has decreased to 5\% after 2016.

Moderate employment growth is observed for the construction (3.2\%), service (5.2\%) and manufacturing (5.4\%) sectors, while employment in the mining and quarrying sector gained momentum during the period, and employment growth reached $7.5 \%$. Also, its productivity increase was the highest among others by $38.6 \%$. According to Aksoy, Konuk and Ak (2020: 77), "the number of firms receiving incentive certificates (in the mining sector) in 2001 was 64, it was 260 in 2013 and 177 in 2017. The number of companies receiving incentive certificates in the mining sector increased rapidly between 2008 and 
2013". Manufacturing labor productivity increased by $7.6 \%$ and services' labor productivity increased by $4.6 \%$. Construction labor productivity decreased by $9.2 \%$ and the total labor productivity decreased by $2 \%$. The productivity in that period seems to have slowed. The political and economic atmosphere might have played a role in this productivity decline.

\subsection{Shift-Share Analysis}

Shift-share analysis gives some clues about the direction of productivity changes in a specific country. Therefore, in order to get some ideas how structural changes are directed during the 2000s in Turkey, shift-share analysis is applied in this study. Basically, three successive periods are chosen: 20032007, 2010-2015 and 2016-2018 as stated above. ${ }^{3}$ The period between 2008 and 2009, when the global economic crisis severely hit the Turkish economy, is excluded from the analysis.

Following Doğruel and Doğruel (2018b), labor productivity (calculated as value added divided by the number of persons employed) during the period selected is decomposed by adding the sub-sectors. As Doğruel and Doğruel (2018b: 275-276) formulated:

$$
P=\frac{V A}{L}=\frac{\sum_{i}^{n} V A i}{\sum_{i}^{n} L i}
$$

For the period $[0, T]$, total labor productivity change is shown as:

$$
P^{T}-P^{0}=\left(\frac{V A}{L}\right)^{T}-\left(\frac{V A}{L}\right)^{0}
$$

The labor productivity in the $\mathrm{i}^{\text {th }}$ sector is calculated as:

$$
P_{i}=\frac{V A_{i}}{L_{i}}
$$

Employment share of the $\mathrm{i}^{\text {th }}$ sector in total manufacturing/ service employment is calculated as:

$S_{i}=\frac{L_{i}}{\sum_{i}^{n} L i}$

Then, equation (2) should be reformulated as:

$P^{T}-P^{0}=\sum_{i}^{n}\left(S_{i}^{T}-S_{i}^{0}\right) P_{i}^{0}+\sum_{i}^{n}\left(S_{i}^{T}-S_{i}^{0}\right)\left(P_{i}^{T}-P_{i}^{0}\right)+\sum_{i}^{n} S_{i}^{0}\left(P_{i}^{T}-P_{i}^{0}\right)$

Where $P_{i}$ refers to labor productivity in the $\mathrm{i}^{\text {th }}$ sector; $S_{i}$ refers to employment share of the $\mathrm{i}^{\text {th }}$ sector in total manufacturing/ service; $[0, \mathrm{~T}]$ refers to time interval, $i=1, \ldots, n$ (sectors).

To see the changes productivity, equation (3) is divided by $P^{0}$.

$$
\frac{P^{T}-P^{0}}{P^{0}}=\frac{\sum_{i}^{n}\left(S_{i}^{T}-S_{i}^{0}\right) P_{i}^{0}}{P^{0}}+\frac{\sum_{i}^{n}\left(P_{i}^{T}-P_{i}^{0}\right) S_{i}^{0}}{P^{0}}+\frac{\sum_{i}^{n}\left(S_{i}^{T}-S_{i}^{0}\right)\left(P_{i}^{T}-P_{i}^{0}\right)}{P^{0}}
$$

$\frac{\sum_{i}^{n}\left(S_{i}^{T}-S_{i}^{0}\right) P_{i}^{0}}{P^{0}}$ refers to "a static shift effect measures productivity growth caused by a shift of labor towards branches with a higher labor productivity level at the beginning of the period", $\frac{\sum_{i}^{n}\left(P_{i}^{T}-P_{i}^{0}\right) S_{i}^{0}}{P^{0}}$ refers to "intra-branch productivity growth", and finally $\frac{\sum_{i}^{n}\left(S_{i}^{T}-S_{i}^{0}\right)\left(P_{i}^{T}-P_{i}^{0}\right)}{P^{0}}$ refers to "dynamic shift effect" which "captures shifts towards more dynamic branches, i.e. branches with higher labor productivity growth rates" (Timmer and Szirmai, 2000: 376). Structural change is divided into "static reallocation effect" due to "the contribution from the reallocation of workers to above average productivity level sectors" and "dynamic reallocation effect" due to "the contribution from the reallocation to above average productivity growth sectors" (Timmer et al., 2014: 3).

The data are taken from (Turkish Statistical Institute (TURKSTAT) Annual Industry and Service Statistics. The data are released according to NACE Rev. 2. As Doğruel and Doğruel (2018b: 277) suggested, the data covering 2000-2002 period are not used because of either some problems in the data in 2002 or the differences in collection of the data before 2001. To see the changes in a broader perspective, 
aggregations of manufacturing industry according to technology and aggregations of services are analyzed through shift-share analysis. The domestic producer price index $(2003=100)$ is used for manufacturing industries, while consumer price index (CPI) is used for service categories. ${ }^{4}$

Table 1: Shift-Share Analysis by Technology Groups (Manufacturing), 2003-2018

\begin{tabular}{l|cccc} 
2003-2007 & $\frac{\sum_{i}^{n}\left(S_{i}^{T}-S_{i}^{0}\right) P_{i}^{0}}{P^{0}}$ & $\frac{\sum_{i}^{n}\left(P_{i}^{T}-P_{i}^{0}\right) S_{i}^{0}}{P^{0}}$ & $\frac{\sum_{i}^{n}\left(S_{i}^{T}-S_{i}^{0}\right)\left(P_{i}^{T}-P_{i}^{0}\right)}{P^{0}}$ & $\frac{P^{T}-P^{0}}{P^{0}}$ \\
\hline LOW & -0.0129 & -0.1693 & -0.0034 & -0.1856 \\
MEDIUM LOW & -0.0417 & -0.2215 & 0.0163 & -0.2469 \\
MEDIUM HIGH & -0.0196 & -0.1846 & 0.0130 & -0.1912 \\
HIGH & -0.0193 & -0.0671 & -0.0048 & -0.0912
\end{tabular}

2010-2015

\begin{tabular}{l|cccc}
\hline LOW & -0.0034 & 0.2000 & -0.0075 & 0.1890 \\
MEDIUM LOW & -0.0223 & 0.3148 & -0.0152 & 0.2772 \\
MEDIUM HIGH & -0.0137 & 0.1779 & -0.0046 & 0.1596 \\
HIGH & -0.0409 & 0.5342 & -0.0273 & 0.4660
\end{tabular}

2016-2018

\begin{tabular}{l|cccc}
\hline LOW & 0.0023 & 0.0926 & 0.001 & 0.096 \\
MEDIUM LOW & 0.0184 & 0.0356 & 0.0047 & 0.059 \\
MEDIUM HIGH & 0.0024 & 0.0987 & 0.0005 & 0.10 \\
HIGH & 0.0025 & 0.1617 & -0.006 & 0.163
\end{tabular}

Note: EUROSTAT Aggregations of Manufacturing Industry (as given in Appendix Table A3) are used, but industry code 30 is assumed to be middle-low-technology depending on Doğruel and Doğruel (2018b) assumption. ${ }^{5}$ Industry code 33 is missing because of missing domestic producer price index and not included in the analysis. Industry code 19 is not available for 2018, so not included in the analysis for the period 2016-2018.

Source: Author calculations from TURKSTAT, Annual Industry and Service Statistics.

Table 1 shows that for the period of 2003-2007, in all manufacturing categories, labor productivity decreased, mostly due to within-sector productivity decreases, and partly due to a shift to the lower productivity sectors. On the other hand, in 2010-2015, labor productivity increased in all manufacturing categories due to within-sector productivity increases. Of particular note has been the increase in labor productivity in high-technology groups in this period. In some sub-sectors, such as other transport equipment $(70.6 \%)$, computer, electronic and optical products (47\%), pharmaceutical $(56.3 \%)$, fabricated metals $(44.2 \%)$, coke and refined petroleum products $(72.2 \%)$, the productivity increase is striking. Particularly, the productivity increase in manufacturing of ships and boats sector reached $76.2 \%$ during the period.

Labor productivity further increased for all groups, but at a slower pace for medium low categories and stagnant for high-tech industries during 2016-2018. In some sectors, productivity increase was very high, such as computer, electronic and optical products (36.2\%), other transport equipment (28.5\%), paper $(24.6 \%)$ and wearing apparel (17.3\%). Especially in air and space craft and related machinery, a $36.5 \%$ increase is observed, which was the highest. 
On the other hand, for the medium high sectors, for example, it is difficult to mention a robust productivity decline, if not an increase. Therefore, analysis in this period still necessitates further research with a wider period of time (including 2019, but not covering years 2020 and 2021 because of the coronavirus outbreaks and their impacts on the Turkish economy). Still, the political and economics incidences stated above in that period might be the reasons for relatively lower productivity growth during the period compared to the previous period (2010-2015).

Figure A4 shows manufacturing and services value-added shares in GDP. The manufacturing share in GDP had reached its peak level (23.1\%) in 1989, and decreased sharply between 1998 and 2002 (from $22 \%$ to $17 \%$ ). It remained at $17 \%$ between 2003 and 2007. The manufacturing share in GDP decreased to $16 \%$ between 2010 and 2015, and increased to $18 \%$ between 2016 and 2018. The services' share was $53 \%$, on average, between 2003 and 2006; however, increased to 55\% in 2007, and fluctuated between 53\% and $54 \%$ in 2010-2015 and 2016-2018.

Industrial policy matters for understanding the structural changes in the manufacturing industry. Türel (2007) pointed out that during the 2000s, the governments ascribed a central role in FDI in facilitating the connection of Turkey with the global world. In addition, "initial approach of the AKP to industrial policy was regional prioritization" (Dincer and Tekin-Koru, 2019: 6). In fact, Atiyas and Bakis (2015: 1225) indicate that "incentive system did not have sectoral selectivity" until 2009. In the crisis years, AKP's policy was to increase government spending to boost demand for decreasing the political cost of the crisis (Dincer and Tekin-Koru, 2019: 8). In addition, with "a new incentive system in 2009" "sectoral selectivity" in industrial policy was introduced and incentives were differentiated "across regions, sectors and the size of investments" (Dincer and Tekin-Koru, 2019: 8). Besides, one industrial policy that was introduced in 2012 (Law No. 3305) changed the incentives regime one more time (Dincer and Tekin-Koru, 2019: 9). Moreover, Yülek (2018) shows the "evolution of industrial policy in Turkey" since the 1950s in his study and pointed out that there had been a change in industrial policy perception since 2011. Since the 1980s, Yülek (2018) stated that the government adopted export-led growth and trade liberalization and followed general industrialization policies, however, after 2011, in addition to these, industrial strategy documents were introduced.

According to Table 2, labor productivity in the service sector shows a somewhat different pattern than that seen in manufacturing in terms of periods. In knowledge-intensive services, productivity became relatively stagnant in 2016-2018, due, in large part, to dynamic and static shifts in these sectors since 2010. Particularly in high-tech service groups, static shift toward relatively lower labor productivity sectors has been observed for almost all periods except 2003-2007. In this period, the increase was especially striking. In less-intensive services, labor productivity decreased in the first period, but increased most notably during the 2010-2015 period.

As can be seen from Figure A4, services share in GDP increased 1 percentage point from 2003-2007 to 2010-2018. An increase in the share of services in total exports has become a common phenomenon not only in developed but also in developing economies. Even, Loungani et al. (2017: 9) pointed out that "services export from developing countries have grown twice as fast compared to advanced economies, growing tenfold since 1990". Developing countries have also substantially increased their "global market share in modern services reaching almost 30\% of global exports. In particular, developing countries have been consistently taking over the world market in Business services (including R\&D, professional, and management consulting), as well as in Intellectual Property and Computer and Information service exports" (Loungani et al., 2017: 9). 
Table 2: Shift-Share Analysis for Aggregate Service Categories 2003-2018

2003-2007

$$
\frac{\sum_{i}^{n}\left(S_{i}^{T}-S_{i}^{0}\right) P_{i}^{0}}{P^{0}} \quad \frac{\sum_{i}^{n}\left(P_{i}^{T}-P_{i}^{0}\right) S_{i}^{0}}{P^{0}} \quad \frac{\sum_{i}^{n}\left(S_{i}^{T}-S_{i}^{0}\right)\left(P_{i}^{T}-P_{i}^{0}\right)}{P^{0}} \quad \frac{P^{T}-P^{0}}{P^{0}}
$$

KNOWLEDGE INTENSIVE SERVICES (FINANCIAL

AND HIGH-TECH

$-0.052$

0.101

0.014

0.063

SERVICES EXCLUDED)

HIGH-TECH SERVICES

$-0.09$

0.342

$-0.091$

0.16

LESS KNOWLEDGE

INTENSIVE SERVICES

0.019

$-0.22$

$-0.008$

$-0.213$

\section{0-2015}

\begin{tabular}{|c|c|c|c|c|}
\hline $\begin{array}{l}\text { KNOWLEDGE INTENSIVE } \\
\text { SERVICES (FINANCIAL } \\
\text { AND HIGH-TECH } \\
\text { SERVICES EXCLUDED) }\end{array}$ & -0.0202 & 0.086 & -0.0017 & 0.0646 \\
\hline HIGH-TECH SERVICES & -0.0949 & 0.009 & 0.019 & -0.066 \\
\hline $\begin{array}{l}\text { LESS KNOWLEDGE } \\
\text { INTENSIVE SERVICES }\end{array}$ & 0.00514 & 0.169315 & -0.00248 & 0.171976 \\
\hline
\end{tabular}

2016-2018

KNOWLEDGE INTENSIVE
SERVICES (FINANCIAL
AND HIGH-TECH
SERVICES EXCLUDED)
HIGH-TECH SERVICES
LESS KNOWLEDGE
INTENSIVE SERVICES

$-0.018$

0.015

$-0.001$

$-0.002$

$-0.042$

0.046

0.0069

0.001

0.0166

0.034

0.011026

0.063

Note: a) EUROSTAT Aggregations of Services (as given in Appendix Table A4) are used. However, NACE Rev.2 60, 89, 91, 92, 94, 97, 98, 99 categories are missing in TURKSTAT database for the period of 2003-2007. Therefore, the statistics related to these sectoral categories are not included. Also, financial services (64-66) are not available in TURKSTAT database. b) We also did shift-share analysis for aggregate service categories for the period between 20102018 in Appendix Table A2.

Source: Author calculations from TURKSTAT, Annual Industry and Service Statistics.

\section{CONCLUSION}

In the 2000s, the Turkish economy experienced high growth rates as well as increasing import dependency and current account deficits. After the crisis, foreign capital inflow continued at higher levels at first, then decreased, but it became more volatile depending on "supporting conditions," which made the country became more vulnerable to unexpected changes in capital flows; therefore, the growth rates were lower and much more fluctuating.

Besides the collapse of savings rates, a decline in the weight of the manufacturing sector generated fragilities in the economy. The shift-share results implies that there is a productivity decline in the manufacturing sector in the first period of AKP. This is mostly derived from the within-sector productivity decrease in almost all technology groups, particularly in middle-low technology groups. In 2010-2015, labor productivity increased in all manufacturing categories due to within-sector productivity increases, 
particularly in high-technology groups in this period. Labor productivity further increased for all groups, but at a slower pace for medium low categories during 2016-2018. Labor productivity in the service sector did not follow the same pattern seen in manufacturing in terms of periods. In knowledge-intensive services, productivity became relatively stagnant in 2016-2018. This has been due in large part to dynamic and static shifts in these sectors since 2010. Particularly in high-tech service groups, static shift toward relatively lower labor productivity sectors has been observed for almost all periods except 2003-2007. Labor productivity in less intensive services only increased during the 2010-2015 period with a most notable growth. Therefore, it is really difficult to articulate shifts to the advanced service sectors in Turkey during the period. In this context, human capital matters most considering the fact that productivity stagnated since 2011 (Patrinos, Psacharopoulos and Tansel, 2019). Del Carpio (2018) already pointed out the "challenges in the quality of. (Turkish) human capital, which limit the growth of productivity" and Turkey might face downside risks "if structural changes-in the education and training system, and the economy more broadly-are not made to ensure that contributions to economic growth come from improvements in productivity".

There are certainly several reasons that affect the productivity changes in manufacturing during the period, but one might be a shift in industrial policy, particularly in the post-2010 period. For the period 2002-2007 the formalization of the informal economy may also have played a role in the decrease in productivity in all sectors in the manufacturing industry. After 2016, the importance of political instability can be emphasized in the decrease in the pace of productivity growth. In addition, the changes in quality of human capital should have a productivity-restricting effect as well. On the other hand, the high productivity increase in some high-tech sectors in 2016-2018 may be the result of a change in industrial policies since 2010 , but that a further study is needed in order to reach such a conclusion.

Finally, even though the period is so short to analyze productivity changes, the results to some extent imply some changes, particularly in the manufacturing industry during the period and necessitates further research.

\section{NOTES}

\footnotetext{
${ }^{1}$ World Trade Organization (WTO) reported that from mid-May to mid-October 2019, "import restricted measures covering an estimated USD 460.4 billion worth of traded merchandise" (WTO, 2019).

2 The term was first used by Bluestone and Harrison in their book The Deindustrialization of America published in 1982.

${ }^{3}$ See Appendix Tables A1 and A2, shift-share analyses for the 2010-2018 period and how it differs from the results of the 2010-2015 period and its compatibility with the results of the 2016-2018 period.

${ }^{4}$ Service producer price index is available after 2017, therefore CPI is used for weighting service industries.

${ }^{5}$ In EUROSTAT technology categorization, 30.3 is classified as high-technology, 30.1 is classified as medium-low-technology, 30-(30.3+30.1) is classified as medium-high-technology. For the period between 2003 and 2007, only two digits NACE Rev. 2 is available. Therefore, 30 was classified in medium-lowtechnology. On the other hand, we also did shift-share analysis for the period between 2010-2018 in Appendix Table A1 taken into account EUROSTAT technology categorization described above, the results do not change much.
} 


\section{AUTHOR STATEMENT}

\section{Research and Publication Ethics Statement}

This study has been prepared in accordance with the ethical principles of scientific research and publication.

\section{Author Contribution}

All authors have contributed the study equally.

\section{Conflict of Interest}

There is no conflict of interest arising from the study for the authors or third parties.

\section{REFERENCES}

Aksoy, M, A. Konuk, H. Ak (2020), "The Effect of Investment Incentives for Mining Sector on the Economic Growth of Turkey", Mineral Resources Management, 36(2), 71-86.

Atiyas, İ., O. Bakis (2015), "Structural Change and Industrial Policy in Turkey", Emerging Markets Finance and Trade, 51(6), 1209-1229, DOI:10.1080/1540496X.2015.1080523

Bakır, E., E. Özçelik, E. Özmen, A. C. Taşıran (2017), “Türkiye'de Erken Sanayisizleşme”, in M. Koyuncu, H. Mıhcı, A. E. Yeldan (eds.), Geçmişten Geleceğe Türkiye Ekonomisi: Fikret Şenses'e Armağan (2nd edition, 157-191), Istanbul: Illetişim Publications.

Baldwin, R. (2016), The Great Convergence: Information Technology and the New Globalization, Cambridge, Massachusetts: The Belknap Press of Harvard University Press.

Boratav, K. (2019), Türkiye İktisat Tarihi 1908-2015, 24th Edition, Turkey, Ankara: İmge Publications.

Dasgupta, S., A. Singh (2006), "Manufacturing, Services and Premature Deindustrialization in Developing Countries: A Kaldorian Analysis", UNU-WIDER Research Paper, No 2006/49.

Del Carpio, X. (2018), “How Low Human Capital Can Limit Productivity Improvements. Examples from Turkey and Peru", Retrieved from http://blogs.worldbank.org/education/how-low-human-capital-canlimitproductivity-improvements-examples-turkey-and-peru, Access Date: 07.06.2021.

Dincer, N., A. Tekin-Koru (2019), "An Anatomy of Productivity in Turkey in the AKP Era through a Political Economy Lens", Munich Personal RePEc Archive Paper No 96844.

Doğruel, F., A. S. Doğruel (2017), "Türkiye'de Sanayileşme ve Kriz", in M. Koyuncu, H. Mıhcı, A.E. Yeldan (eds.), Geçmişten Geleceğe Türkiye Ekonomisi: Fikret Şenses'e Armağan (2nd edition, 45-73), Istanbul: iletişim Publications.

Doğruel, F., A. S. Doğruel (2018a), Bıçak Sırtında Büyüme ve İstikrar: Küreselleşmenin Yükselişi ve Düşüşü, (2nd edition), Istanbul: Bilgi University Publications

Doğruel, A. S., F. Doğruel (2018b), “Türkiye'de Yapısal ve Teknolojik Değişme”, in N. Engin, E. Aslanoğlu, O. Erdoğan, B.C. Karahasan, K. Tata (eds.), Türkiye Ekonomisinde Kalkınma ve Dönüşüm: Taner Berksoy’a Armağan, Ankara: Imge Publications, 267-286.

EUROSTAT (2021), "Eurostat indicators on High-tech industry and Knowledge - intensive services",

https://ec.europa.eu/eurostat/cache/metadata/Annexes/htec esms an3.pdf, Access Date: 15.03.2020.

Gereffi, G. (2015), “Global Value Chains, Development and Emerging Economies”, Inclusive and Sustainable Industrial Development Working Paper Series WP 18.

Hausmann, R., D. Rodrik, A. Velasco (2008), "Growth Diagnostics", The Washington Consensus Reconsidered: Towards a new Global Governance, Oxford University Press, 324-355.

Kose, M. A., E. Prasad, K. Rogoff, S. J. Wei (2009), “Financial Globalization: A Reappraisal”, IMF Staff Papers, 56(1), 862. 
Kucera, D., X. Jiang (2019), "Structural Transformation in Emerging Economies: Leading Sectors and the Balanced Growth Hypothesis", Oxford Development Studies, 47(2), 188-204, DOI: 10.1080/13600818.2018.1533934.

Loungani, P., S. Mishra, C. Papageorgiou, K. Wang (2017), "World Trade in Services: Evidence from A New Dataset", IMF Working Paper, WP/17/77.

Meçik, O., U. Aytun (2018), "Türkiye Ekonomisinde Erken Sanayisizleşmeye Bölgesel Bir Yaklaşım”, METU Studies in Development, 45(1), 59-81.

Orhangazi, Ö. (2019), "Türkiye Ekonomisinin Yapısal Sorunları, Finansal Kırılganlıklar ve Kriz Dinamikleri”, Mülkiye Dergisi, 43(1), 111-137.

Rodrik, D. (2016), "Premature Deindustrialization", Journal of Economic Growth, 21(1), 1-33. https://doi.org/10.1007/s10887-015-9122-3.

Öniş, Z. (2019), "Turkey under the Challenge of State Capitalism: The Political Economy of the late AKP Era", Southeast European and Black Sea Studies, 19(2), 201-225, DOI: 10.1080/14683857.2019.1594856.

Patrinos, H. A., G. Psacharopoulos, A. Tansel (2019), "Returns to Investment in Education: The Case of Turkey", MPRA Paper No. 92933.

Timmer, M. P., A. Szirmai (2000), "Productivity Growth in Asian Manufacturing: The Structural Bonus Hypothesis Examined", Structural Change and Economic Dynamics, 11(4), 371-392.

Timmer, M. P., G. de Vries, K. de Vries (2014), "Patterns of Structural Change in Developing Countries”, Groningen Growth and Development Centre Research Memorandum 149, 1-29.

Turkish Statistical Institute (2020), Annual Industry and Service Statistics, https://data.tuik.gov.tr/Kategori/GetKategori?p=sanayi-114\&dil=2 , Access Date: 14.09.2020.

Türel, O. (2007), “Türkiye'de Sanayi Politikalarının Dünü ve Bugünü”, Bildiri, Ankara, TMMOB Sanayi Kongresi.

Van Neuss, L. (2016), "The Economic Forces Behind Deindustrialization: An Empirical Investigation", 1-50, Retrieved from https://ssrn.com/abstract=2817332, Accessed Date: 14.09.2020.

World Bank Enterprise Survey (2019), https://www.enterprisesurveys.org/en/data, Access Date: 14.05.2021.

World Bank (2020), World Development Indicators, https://databank.worldbank.org/source/world-developmentindicators, Access Date: 19.05.2020.

Yeldan, E., D. Yıldırım (2015), "Küreselleşme ve Sanayisizleşme Bağlamında Türkiye'de ve Dünyada Demokrasi Açı̆̆ı”, Çalışma ve Toplum, 45(2), 65-88.

Yülek, M. A. (2018), "Thinking About a New Industrial Policy Framework for Turkey", in A.F. Aysan, M. Babacan, N. Gür, H. Karahan (eds.), Turkish Economy: Between Middle Income Trap and High Income Status, Palgrave Macmillan, Cham, 287-317, https://doi.org/10.1007/978-3-319-70380-0 13. 


\section{APPENDIX}

Figure A1: Net Financial Flows and GDP Growth Rate, 1989-2018

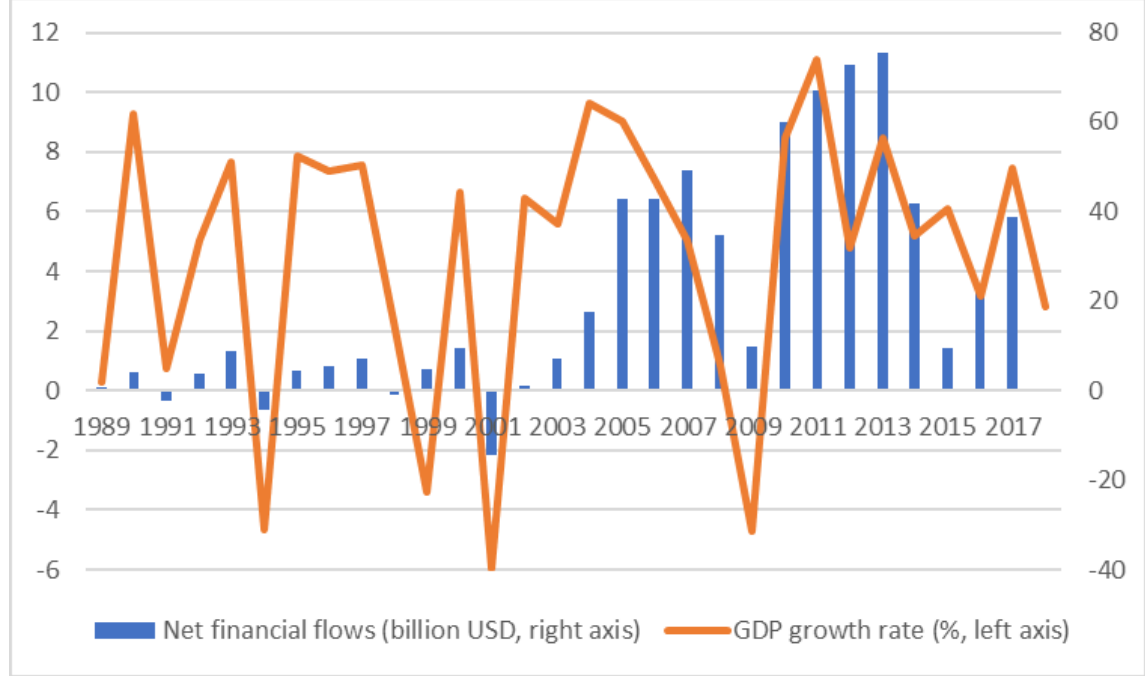

Source: World Bank (2020), Balance of Payments, CBRT EVDS; World Bank (2020)

Figure A2: GDP per Capita (Constant LCU) (Logarithmic), 1998-2018

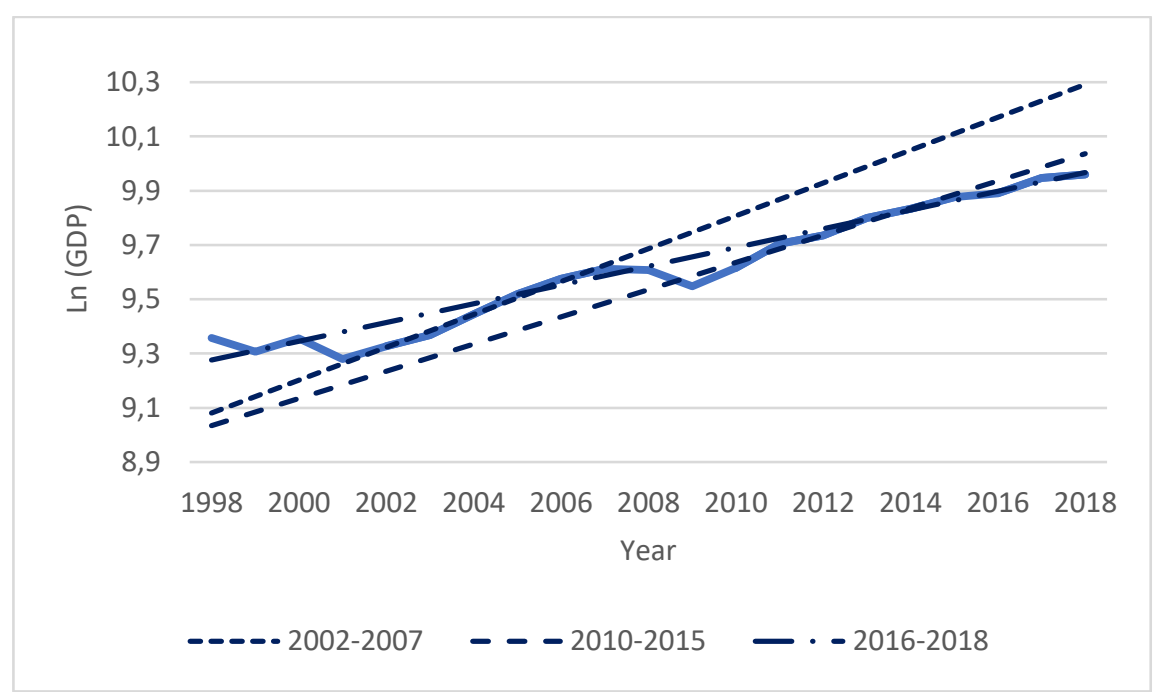

Note: GDP in constant local currency unit (LCU) statistics are taken from World Development Indicators (2020). Data is equal to the TURKSTAT GDP by expenditure approach (2009 base) in chain linked volume series. Following Boratav (2019: 254), growth rate is calculated as logarithmic trend value of GDP at constant prices.

Source: World Bank (2020). 
Figure A3: Current Account Balance (\% of GDP), 1974-2018

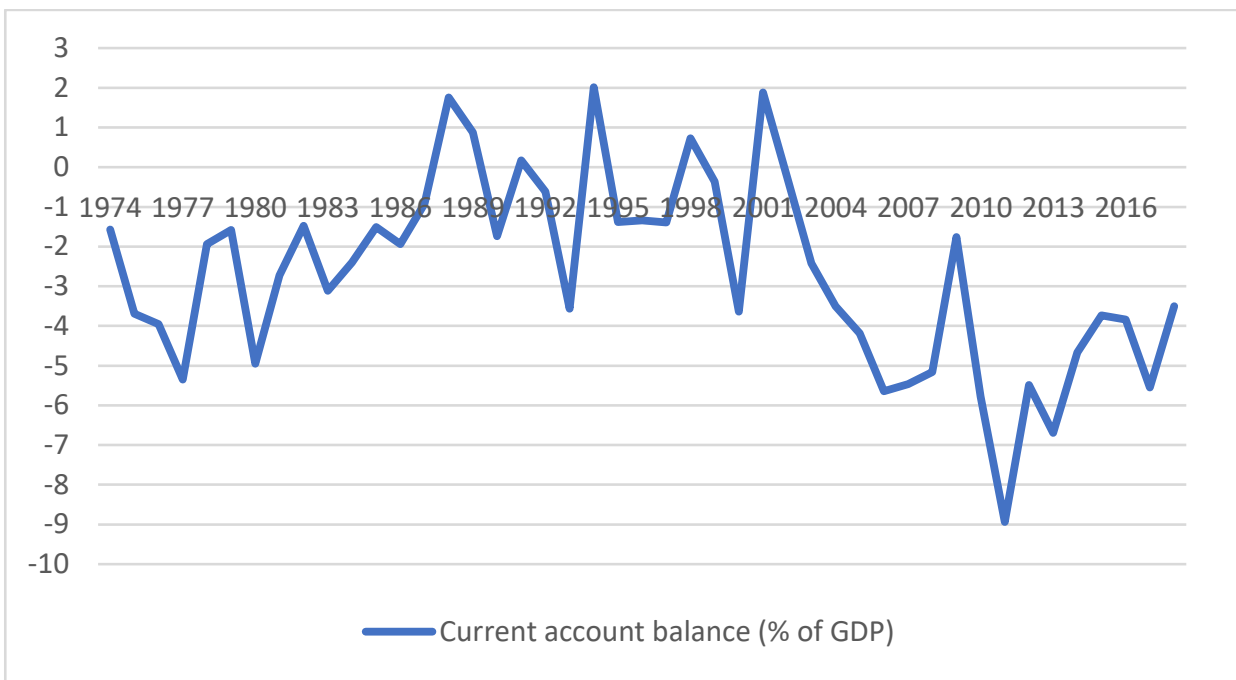

Source: World Bank (2020)

Figure A4: Agriculture, Manufacturing and Services Value-Added Shares in GDP (\%), 1960-2018

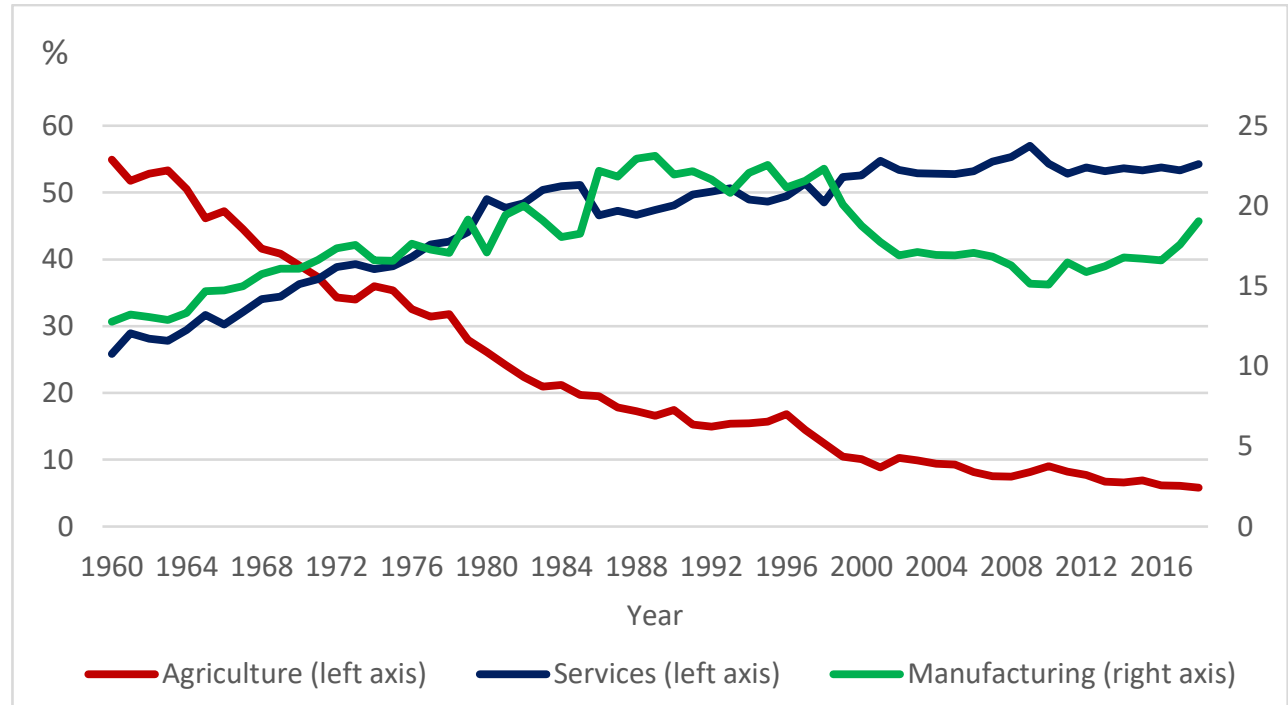

Source: World Bank (2020). 
Table A1: Shift-Share Analysis by Technology Groups (Manufacturing), 2010-2018

\begin{tabular}{l|cccc} 
& $\frac{\sum_{i}^{n}\left(S_{i}^{T}-S_{i}^{0}\right) P_{i}^{0}}{P^{0}}$ & $\frac{\sum_{i}^{n}\left(P_{i}^{T}-P_{i}^{0}\right) S_{i}^{0}}{P^{0}}$ & $\frac{\sum_{i}^{n}\left(S_{i}^{T}-S_{i}^{0}\right)\left(P_{i}^{T}-P_{i}^{0}\right)}{P^{0}}$ & $\frac{P^{T}-P^{0}}{P^{0}}$ \\
\hline LOW & 0.001 & 0.422 & -0.004 & 0.419 \\
MEDIUM LOW & -0.004 & 0.509 & -0.003 & 0.50 \\
MEDIUM HIGH & -0.01 & 0.37 & -0.01 & 0.349 \\
HIGH & -0.036 & 0.97 & -0.015 & 0.92
\end{tabular}

Table A2: Shift-Share Analysis for Aggregate Service Categories 2010-2018

\begin{tabular}{l|cccc} 
& $\frac{\sum_{i}^{n}\left(S_{i}^{T}-S_{i}^{0}\right) P_{i}^{0}}{P^{0}}$ & $\frac{\sum_{i}^{n}\left(P_{i}^{T}-P_{i}^{0}\right) S_{i}^{0}}{P^{0}}$ & $\frac{\sum_{i}^{n}\left(S_{i}^{T}-S_{i}^{0}\right)\left(P_{i}^{T}-P_{i}^{0}\right)}{P^{0}}$ & $\frac{P^{T}-P^{0}}{P^{0}}$ \\
\hline $\begin{array}{l}\text { KNOWL-2018 } \\
\text { SERVICES (FINANCIAL }\end{array}$ & -0.041 & 0.105 & 0.004 & 0.068 \\
$\begin{array}{l}\text { AND HIGH-TECH } \\
\text { SERVICES EXCLUDED) }\end{array}$ & & & & \\
HIGH-TECH SERVICES & -0.155 & 0.095 & 0.045 & -0.014 \\
$\begin{array}{l}\text { LESS KNOWLEDGE } \\
\text { INTENSIVE SERVICES }\end{array}$ & 0.02 & 0.307 & 0.015 & 0.345
\end{tabular}


Table A3: EUROSTAT Aggregations of Manufacturing Industry

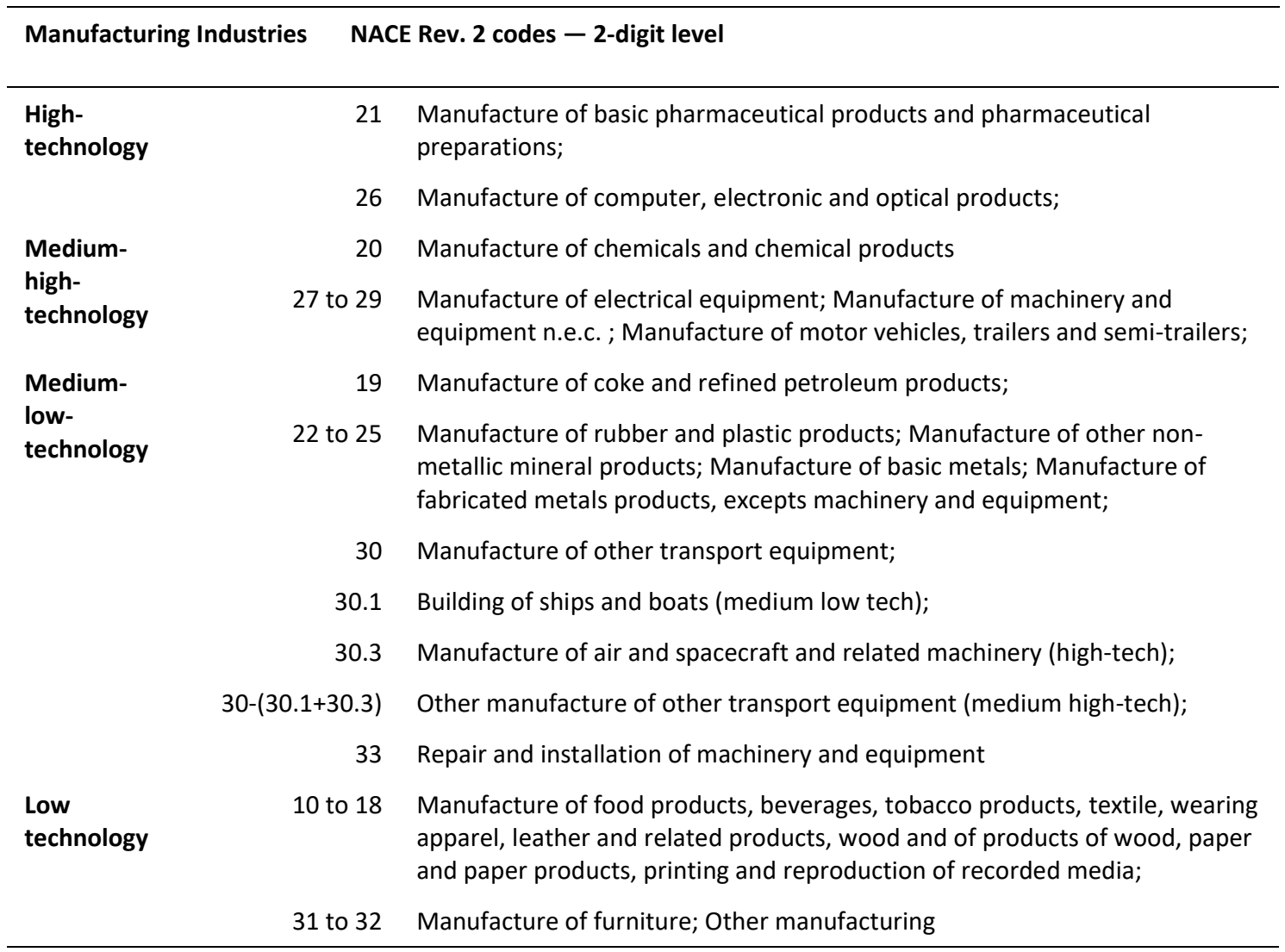

Note: EUROSTAT Aggregations of Manufacturing Industry are used, but industry code 30 is assumed to be middle-low-technology depending on Doğruel and Doğruel (2018b) assumption. 
Table A4: EUROSTAT Aggregations of Services

\begin{tabular}{|c|c|c|}
\hline Knowledge based & NACE Rev & 2 codes - 2-digit level \\
\hline \multirow{7}{*}{$\begin{array}{l}\text { Knowledge- } \\
\text { intensive services } \\
\text { (excluding high-tech } \\
\text { and financial } \\
\text { services; including } \\
\text { other) }\end{array}$} & $\begin{array}{r}50 \text { to } \\
51\end{array}$ & Water transport; Air transport; \\
\hline & 58 & Publishing activities (section J); \\
\hline & $\begin{array}{r}69 \text { to } \\
71\end{array}$ & $\begin{array}{l}\text { Legal and accounting activities; Activities of head offices, management } \\
\text { consultancy activities; Architectural and engineering activities, technical } \\
\text { testing and analysis (section M); }\end{array}$ \\
\hline & $\begin{array}{r}73 \text { to } \\
75\end{array}$ & $\begin{array}{l}\text { Advertising and market research; Other professional, scientific and technical } \\
\text { activities; Veterinary activities (section M); }\end{array}$ \\
\hline & 78 & Employment activities; \\
\hline & 80 & Security and investigation activities; \\
\hline & $\begin{array}{r}84 \text { to } \\
93\end{array}$ & $\begin{array}{l}\text { Public administration and defence, compulsory social security (section } \mathrm{O} \text { ); } \\
\text { Education (section P), Human health and social work activities (section Q); } \\
\text { Arts, entertainment and recreation (section R). }\end{array}$ \\
\hline \multirow[t]{2}{*}{$\begin{array}{l}\text { High-tech } \\
\text { knowledge- } \\
\text { intensive services }\end{array}$} & $\begin{array}{r}59 \text { to } \\
63\end{array}$ & $\begin{array}{l}\text { Motion picture, video and television programme production, sound } \\
\text { recording and music publish activities; Programming and broadcasting } \\
\text { activities; Telecommunications; computer programming, consultancy and } \\
\text { related activities; Information service activities (section J); }\end{array}$ \\
\hline & 72 & Scientific research and development (section $\mathrm{M}$ ); \\
\hline $\begin{array}{l}\text { Knowledge- } \\
\text { intensive financial } \\
\text { services }\end{array}$ & $\begin{array}{r}64 \text { to } \\
66\end{array}$ & Financial and insurance activities (section $\mathrm{K}$ ); \\
\hline \multirow[t]{12}{*}{$\begin{array}{l}\text { Less knowledge- } \\
\text { intensive services }\end{array}$} & $\begin{array}{r}45 \text { to } \\
47\end{array}$ & $\begin{array}{l}\text { Wholesale and retail trade; Repair of motor vehicles and motorcycles } \\
\text { (section G); }\end{array}$ \\
\hline & 49 & Land transport and transport via pipelines; \\
\hline & $\begin{array}{r}52 \text { to } \\
53\end{array}$ & $\begin{array}{l}\text { Warehousing and support activities for transportation; Postal and courier } \\
\text { activities; }\end{array}$ \\
\hline & $\begin{array}{r}55 \text { to } \\
56\end{array}$ & Accommodation and food service activities (section I); \\
\hline & 68 & Real estate activities (section $\mathrm{L}$ ); \\
\hline & 77 & Rental and leasing activities; \\
\hline & 79 & Travel agency, tour operator reservation service and related activities; \\
\hline & 81 & Services to buildings and landscape activities; \\
\hline & 82 & Office administrative, office support and other business support activities; \\
\hline & $\begin{array}{r}94 \text { to } \\
96\end{array}$ & $\begin{array}{l}\text { Activities of membership organisation; Repair of computers and personal and } \\
\text { household goods; Other personal service activities (section S); }\end{array}$ \\
\hline & 97 to & Activities of households as employers of domestic personnel; \\
\hline & 99 & $\begin{array}{l}\text { Undifferentiated goods- and services-producing activities of private } \\
\text { households for own use (section T); Activities of extraterritorial organisations } \\
\text { and bodies (section U). }\end{array}$ \\
\hline
\end{tabular}


Table A5: Changes in Employment and Labor Productivity by Sectors

\begin{tabular}{|c|c|c|c|c|c|c|c|}
\hline & & \multicolumn{3}{|c|}{ Change in employment (\%) } & \multicolumn{3}{|c|}{ Change in labor productivity (\%) } \\
\hline & & 2003-2007 & $\begin{array}{l}2010- \\
2015\end{array}$ & 2016-2018 & 2003-2007 & 2010-2015 & 2016-2018 \\
\hline \multicolumn{2}{|l|}{ Total } & 47.3 & 39.3 & 4.9 & -21.7 & 13.4 & -2.0 \\
\hline \multicolumn{2}{|c|}{ Mining and quarrying } & 32.5 & 6.3 & 7.5 & 5.9 & -16.6 & 38.6 \\
\hline \multicolumn{2}{|l|}{ Construction } & 155.8 & 69.5 & 3.2 & -42.4 & 7.6 & -9.2 \\
\hline \multicolumn{2}{|l|}{ Services } & 51.6 & 36.4 & 5.2 & -15.7 & 11.0 & 4.6 \\
\hline \multicolumn{2}{|c|}{ Manufacturing } & 27.1 & 36.4 & 5.4 & -21.6 & 18.3 & 7.6 \\
\hline \multicolumn{2}{|c|}{ Low technology } & 14.5 & 33.9 & 4.7 & -18.6 & 18.9 & 9.6 \\
\hline 10 & Food & 13.7 & 37.2 & 5.2 & -21.7 & 1.6 & 8.0 \\
\hline 11 & Beverages & -2.3 & 19.6 & 8.6 & 23.5 & -14.0 & 2.3 \\
\hline 12 & Tobacco & -25.0 & -51.6 & 15.1 & 48.6 & - & - \\
\hline 13 & Textiles & 1.3 & 31.7 & 4.9 & -17.3 & 29.4 & 6.4 \\
\hline 14 & Wearing apparel & 15.2 & 33.9 & 6.9 & -28.6 & 29.3 & 17.3 \\
\hline 15 & Leather & 21.2 & 29.5 & 2.5 & -26.5 & 13.3 & 1.9 \\
\hline 16 & Wood & 38.1 & 21.1 & 1.7 & 30.9 & 24.4 & 1.4 \\
\hline 17 & Paper & 44.4 & 48.4 & 5.6 & -9.8 & 34.3 & 24.6 \\
\hline 18 & Print. and rep. of rec. $\mathrm{m}$. & 42.9 & 7.1 & -3.0 & -25.9 & 43.2 & 1.8 \\
\hline 31 & Furniture & 25.6 & 63.0 & -0.4 & -16.7 & -2.0 & -1.0 \\
\hline 32 & Other manuf. & 43.4 & 9.1 & 6.7 & -7.0 & 52.1 & 2.0 \\
\hline \multicolumn{2}{|c|}{ Medium-low-technology } & 51.3 & 37.6 & 4.3 & -24.7 & 27.7 & 5.9 \\
\hline 19 & Coke and ref. petrol. & 10.1 & 14.6 & - & -23.5 & 72.2 & - \\
\hline 22 & Rubber and plastic & 36.0 & 44.0 & 5.6 & -23.6 & 16.1 & 3.4 \\
\hline 23 & Other non-metallic min. & 53.2 & 35.0 & 3.0 & -11.0 & 14.8 & -0.8 \\
\hline 24 & Basic metals & 38.1 & 29.3 & 8.3 & -34.7 & 30.2 & -1.9 \\
\hline 25 & Fabricated metals & 64.6 & 42.5 & 1.5 & -19.8 & 44.2 & 1.1 \\
\hline 30 & Other transport eq. & 87.4 & 13.3 & 19.9 & 5.6 & 70.6 & 28.5 \\
\hline 30.1 & Ships and boats & - & -17.2 & 21.7 & - & 76.2 & -3.3 \\
\hline 30.3 & $\begin{array}{l}\text { Air \& spacecraft and rel. } \\
\text { mach. }\end{array}$ & - & 67.8 & 35.8 & - & 46.4 & 36.5 \\
\hline $30-(30.1+30.3)$ & Other & - & 23.0 & 2.9 & - & 45.1 & 33.6 \\
\hline \multicolumn{2}{|c|}{ Medium-high-technology } & 43.9 & 40.1 & 7.3 & -19.1 & 16.0 & 10.2 \\
\hline 20 & Chemicals & 6.8 & 21.8 & 8.8 & -30.7 & 29.6 & 11.9 \\
\hline 27 & Electrical equipment & 51.0 & 42.7 & 5.5 & -11.9 & 9.5 & 4.3 \\
\hline 28 & Machinery and equipment n.e.c. & 45.3 & 46.2 & 7.6 & -8.5 & 32.1 & 11.3 \\
\hline 29 & Motor vehicles & 58.5 & 40.1 & 8.1 & -17.7 & 8.1 & 10.9 \\
\hline \multicolumn{2}{|c|}{ High-technology } & 8.9 & 23.8 & 13.8 & -9.1 & 46.6 & 16.4 \\
\hline 21 & Pharmaceutical & -0.2 & 8.1 & 14.6 & -1.0 & 56.3 & 5.0 \\
\hline 26 & $\begin{array}{l}\text { Computer, electronic and } \\
\text { optical products }\end{array}$ & 18.4 & 41.9 & 13.0 & -16.2 & 47.1 & 36.2 \\
\hline
\end{tabular}

Note: Total value added at factor cost is deflated by total producer price index. Mining and quarrying, and manufacturing value added data are deflated by sectoral PPI's. Construction value added is deflated by total PPI. Service sector value added is deflated by consumer price index. Moreover, individual industries are deflated by their sectoral PPI's.

Source: Author calculations from TURKSTAT (2020). 